\title{
TOTAL QUALITY MANAGEMENT AND SME PERFORMANCE: THE MEDIATING EFFECT OF INNOVATION IN MALAYSIA
}

\author{
Nurazree Mahmud ${ }^{1 *}$, Mohd Faiz Hilmi ${ }^{2}$, Yanti Aspha Ameira Mustapha ${ }^{3}$ \\ and Rizuwan Abu Karim ${ }^{4}$ \\ ${ }^{1}$ Faculty of Business and Management, Universiti Teknologi MARA Melaka, \\ E-mail: nurazree642@melaka.uitm.edu.my \\ ${ }^{2}$ School of Distance Education, Universiti Sains Malaysia, Malaysia \\ E-mail: faiz@usm.edu.my \\ ${ }^{3}$ Faculty of Business and Management, Universiti Teknologi MARA Kedah, \\ E-mail: ameira574@kedah.uitm.edu.my \\ ${ }^{4}$ Faculty of Business and Management, Universiti Teknologi MARA Melaka, \\ E-mail: rizuwan305@bdrmelaka.uitm.edu.my
}

\begin{abstract}
The purpose of this study was to discover the crucial issues between TQM and the performance of Malaysian SMEs. This paper also reviewed the need of the other variable in the relationship between TQM and Malaysian SME's performance; namely innovation. This paper then presents the empirical results carried out on the Malaysian SMEs covering the manufacturing industry. The measurement scale in this study was tested and found to be reliable and valid to examine the research model. The 124 samples obtained were assessed using Smart PLS in order to examine the structural equation model. Empirical findings in this study prove that TQM had an insignificant impact on innovation and performance. Moreover, innovation mediates the relationship between TQM and performance of SMEs in Malaysia. This study provides new evidence in the important area of TQM and innovation of Malaysian SMEs.
\end{abstract}

Keywords: TQM, innovation, SME performance, manufacturing, Malaysia

$\underline{\text { ARTICLE INFO }}$

Article History:

Received: 26 December 2018

Accepted: 28 March 2019

Published: 30 April 2019 


\section{INTRODUCTION}

Small and medium enterprises (SMEs) play a crucial role in economic development especially in developing countries by contributing to overall industrial production, generating employment and reducing poverty (Arinaitwe, 2006; Aziz et al., 2014). According to the ASEAN Secretariat data, SMEs generate employment between $50 \%$ to $95 \%$, contribute between $30 \%$ to $53 \%$ to GDP (gross domestic product) and generate $19 \%$ to $31 \%$ of the total exports in ASEAN (Asia News Monitor, 2011). Malaysian SMEs, account for $99.2 \%$ of the total business establishments, contribute $32 \%$ of GDP, $59 \%$ of employment, and generate $19 \%$ of the total exports to other countries (SME Corporation Malaysia, 2012). However, the contribution of SMEs to GDP in Malaysia is still much lower compared to other middleincome countries with $39 \%$ and $51 \%$ for high-income countries (SME Corporation Malaysia, 2015, in SME Annual Report, 2014). Nevertheless, it also shows how important SMEs are in shaping the Malaysian economic landscape and remain as the backbone of the industrial development in the country (Aziz et al., 2014; Saleh et al., 2006).

SMEs which face difficulties and challenges from the competitive business environment would be hindered to achieve sustainable growth. Quality is one of the major barriers that might hinder SMEs' growth (Mat Yunoh \& Mohd Ali, 2015). Hence, SMEs were forced to put more concentration on quality management systems (QMS). QMS can enhance the quality of products or services offered by SMEs and this system is recognised as a platform to spur quality-related activities in organisations (Oke \& Oke, 2014). In addition, Malaysian SMEs also have a low level of technology, innovation, and R\&D (Abdullah et al., 2009; Ng \& Kee, 2012). The percentage of innovating companies for small companies is still low compared to large companies with $74.26 \%$ for large companies and $35.75 \%$ for small companies (MASTIC, 2011).

This research is directed to explore the performance of Malaysian SMEs and intend to fill these research gaps through examining some practices of management or organisational factors in strategic management as a strategy to improve their performance. There are many previous studies examining either theoretically or empirically on Total Quality Management (TQM) application and implementation in organisations in the last two decades. 
However, previous studies relating TQM to organisational performance provide mixed and inconclusive results (Brah \& Lim, 2006; CarmonaMarquez et al., 2016; Elmuti et al., 1996; Hubiak \& O’Donnell, 1996). These mixed and inconsistent results have led many scholars to propose to include other factors as mediators in order to influence the existing relationship (refer to TQM and business performance for this study) (Macaes et al., 2007; Pinho, 2008). This study aims to include other factors as mediators to determine the linkage between TQM and SME performance and, hence offer alternative perspectives in extending the existing knowledge. In order to bridge this gap, an investigation is truly needed by having innovation as a mediator of the relationship between TQM and SME performance since there is a dearth of studies that examine innovation, as a mediator of the relationship between TQM and SME performance, especially in the Malaysian context.

\section{LITERATURE REVIEW}

\section{TQM and SME Performance}

There is a relatively large body of empirical studies that measure business performance from a TQM perspective. The findings indicate that more research is needed on TQM practices and business performance. However, despite the significant relationship between TQM and performance, some recent studies have found negative and insignificant relationships between TQM practices and SME performance. For instance, recent findings show that customer focus and continuous improvement did not support SME performance (Jabeen et al., 2015). In addition, the impact of TQM toward business performance is also not established although the link is significant towards operational and quality performance (Danyen \& Callychurn, 2015). These examples of inconsistent findings on TQM and performance show that the recent trends also published mixed results with regards to the linkage between TQM and performance.

\section{TQM and Innovation}

It is also crucial to stress that TQM dimensions, namely process management and people management, are among the important factors in building innovation capabilities, which in turn will spur and generate skills 
and capabilities in organisations (Yusr et al., 2014). People management or a human-based approach is important in shaping a quality culture in organisations and finally promoting an innovation culture. Despite to this positive influence, in searching relevant previous studies, there were inconsistent and mixed findings of TQM and innovation (Laforet, 2011; Zehir et al., 2012). The researchers believed and highlighted several reasons why the implementation of TQM might have a negative impact on innovation performance. One of the reasons might be due to that TQM by itself could trap organisational improvement or incremental innovation, and this practices leads organisations to be narrow minded.

\section{Innovation and SME Performance}

Past studies revealed the relationship between innovativeness and organizational performance from the perspective of a customer or a market view (Akgün et al., 2009; Gunday et al., 2011). Furthermore, some past research also highlighted on the impact of innovation towards organisational performance. For instance, the impacts in terms of organisational effectiveness, such as based on productivity of a firm (Gunday et al., 2011; Lin \& Chen, 2007; McDermott \& Prajogo, 2012; Noruzy et al., 2012) and from a financial perspective, for instance profitability (Camisón \& Villarlópez, 2014; Gunday et al., 2011; McDermott \& Prajogo, 2012; Oke et al., 2007). The findings by Oke et al. (2007) show that the SMEs are more focussedon incremental rather radical innovations. The results prove that there is a connection between innovation and performance derived from sales turnover growth in SMEs. This confirms the impact of innovation in organisations and provides a good basis for the re-emergence of innovation activities in SMEs.

\section{Innovation Mediates TQM and SME Performance}

The use of a mediator in relation to TQM and performance also caught the attention of other researchers. Ruiz-Moreno et al. (2015) believed there are other strategic resources which will influence organisational performance rather than depending on TQM solely. These researchers urged other researchers to concentrate on innovation since innovation and other capabilities will improve the implementation of TQM in organisations. The findings relating to innovation as a mediator are also supported by Dedy 
et al. (2016). They were able to prove that the mediating role of process innovation in establishing a link between TQM and firm performance. In addition, Sadikoglu and Zehir (2010) proved that there is an impact of innovation as a mediator in which TQM and firm performance was mediated by innovation performance and employee performance.

Based on above statements, it is crucial to examine the impact of innovation as a mediator on the existing relationship between TQM and SME performance particularly in an emerging economy like Malaysia. Concerning the impact of TQM and innovation as one of the established strategic factor that gives a positive impact on organisational performance, this study proposes the following hypotheses:

$\mathbf{H}_{\mathbf{1}}$ : TQM has a relationship with SME Performance.

$\mathbf{H}_{2}$ : TQM has a relationship with Innovation of SMEs

$\mathbf{H}_{3}$ : Innovation has a relationship with SME Performance

$\mathbf{H}_{4}$ : The relationship between TQM and SME Performance is mediated by innovation

\section{METHODOLOGY}

\section{Procedures and Sample}

This study used a sample derived from the Federation of Malaysian Manufacturers (FMM) and only focused on certain SMEs mainly in the manufacturing industry with ISO certification (813 companies). The systematic probability sampling was applied to select the element in the sampling frame. For this purpose, every third element in the sampling frame was selected, that provided 250 elements or companies. From those 250 companies, a link embedded for an online survey was sent via email to companies that had provided their email as part of their profile in the FMM directory. 124 valid responses were received and the recipients were either the owners or managers in their organisation. The decision in selecting the minimum sample size was based on (Hair et al., 2014), in which the minimum sample size recommended is at least 59 responses with a significance rate of $5 \%$ and $0.25 \%$ of minimum $\mathrm{R}^{2}$ for PLS-SEM. 


\section{Measures}

TQM was defined as seven practices namely; (1) leadership, (2) strategic planning, (3) customer focus, (4) information and analysis, (5) people management, (6) process management, and (7) supplier quality management. With respect on the scale between "1" - "5" ("1" denotes "strongly disagree" and " 5 " denotes "strongly agree"), respondent identified their perception of TQM practices applied in their organisations. There were two categories specifying innovation in the organization, namely organisational innovation and technological innovation. These adapted items were taken from (Camisón \& Villar-López, 2014; Keskin, 2006; Calantone et al., 2002) and were expressed on the scale ranging from "1" - "5" ("1" denotes "strongly disagree" and "5" denotes "strongly agree").

In addition, measurement of SME performance was + based on two different measures; financial and non-financial items as proposed by Salaheldin, (2009). Over the past 12 months, respondents identified their organisation's performance and gave a rating based on the scale ranging from 1 representing "greatly decreased" to 5 representing "greatly increased".

\section{Structural Equation Modeling and Analysis of Mediator}

The SmartPLS version 3.0 was used to examine the structural equation modeling. In an effort to establish the model, wo different stages namely the measurement model and the structural model were used. The measurement model need to be tested in terms of reliability, and validity in order to establish a good prediction of items before proceeding to the next stage. While, the structural model was used in order to test the prediction of the model and the impact of innovation as a mediator of the relationship between TQM and performance was tested based on a hierarchical regression analyses of the total effect, direct effect, and bootstrapping approach (Hair et al., 2014). 


\section{RESULT AND DISCUSSION}

\section{Description of the Sample}

Based on the SMEs response, the majority of companies were obtained from the food and beverages category that represented $22.6 \%$, followed by the electrical and electronics category which consisted of $15.3 \%$. The data also represented the business category focusing on machinery and equipment with $12.9 \%$. A majority of the companies $62.9 \%$ established their business more than 15 years ago. With respect to the location of the companies, the majority of the companies were located in Selangor with $34.7 \%$ and the remaining of them were from various places such as in Melaka, Penang, Negeri Sembilan, Pahang and other states in Malaysia.

\section{Measurement Model}

A summary of the results based on convergent validity and internal reliability are presented in Table 1. Loading of each items as well as composite reliability (CR), and average variance extracted (AVE) were used to quantify convergent validity (Fornell \& Larcker, 1981). The result shows that, the factor loading for all items were in the range of $0.710-0.888$ and exceeded the minimum level of 0.7. In addition, the AVE also exceed the minimum recommended level of 0.5 (Hair et al., 2010) in which the data recorded in the range of 0.625 to 0.760 , While, CR also passed its minimum recommended level of 0.7 (Fornell \& Larcker, 1981) and ranged from 0.815 to 0.9221 .

Table 1: Finding of Measurement Model

\begin{tabular}{lcccc}
\hline \multicolumn{1}{c}{ Construct } & Measurement Item & Loading & AVE & CR \\
\hline Leadership & L1 & 0.830 & 0.663 & 0.907 \\
& L2 & 0.871 & & \\
L3 & 0.849 & & \\
& L4 & 0.753 & & \\
\hline Strategic Planning & L5 & 0.760 & & \\
& SP1 & 0.844 & 0.704 & 0.922 \\
& SP2 & 0.827 & &
\end{tabular}




\begin{tabular}{|c|c|c|c|c|}
\hline Construct & Measurement Item & Loading & AVE & CR \\
\hline & SP3 & 0.770 & & \\
\hline & SP4 & 0.883 & & \\
\hline & SP5 & 0.867 & & \\
\hline \multirow[t]{5}{*}{ Customer Focus } & CF1 & 0.710 & 0.633 & 0.873 \\
\hline & CF2* & 0.611 & & \\
\hline & CF3 & 0.799 & & \\
\hline & CF4 & 0.854 & & \\
\hline & CF5 & 0.813 & & \\
\hline \multirow[t]{5}{*}{ Information and Analysis } & IA1 & 0.853 & 0.701 & 0.921 \\
\hline & IA2 & 0.840 & & \\
\hline & IA3 & 0.864 & & \\
\hline & IA4 & 0.822 & & \\
\hline & IA5 & 0.804 & & \\
\hline \multirow[t]{5}{*}{ People Management } & PM1 & 0.732 & 0.605 & 0.859 \\
\hline & $\mathrm{PM}^{*}$ & 0.650 & & \\
\hline & PM3 & 0.790 & & \\
\hline & PM4 & 0.817 & & \\
\hline & PM5 & 0.768 & & \\
\hline \multirow[t]{5}{*}{ Process Management } & PR1* & 0.600 & 0.628 & 0.870 \\
\hline & PR2 & 0.775 & & \\
\hline & PR3 & 0.732 & & \\
\hline & PR4 & 0.860 & & \\
\hline & PR5 & 0.798 & & \\
\hline \multirow[t]{4}{*}{$\begin{array}{l}\text { Supplier } \text { Quality } \\
\text { Management }\end{array}$} & SQ1 & 0.798 & 0.595 & 0.815 \\
\hline & SQ2 & 0.740 & & \\
\hline & SQ3 & 0.775 & & \\
\hline & SQ4* & 0.471 & & \\
\hline \multirow[t]{3}{*}{ Organisational Innovation } & Ol1 & 0.769 & 0.633 & 0.873 \\
\hline & $\mathrm{OI} 2$ & 0.862 & & \\
\hline & $\mathrm{OI3}^{*}$ & 0.575 & & \\
\hline
\end{tabular}




\begin{tabular}{|c|c|c|c|c|}
\hline Construct & Measurement Item & Loading & AVE & CR \\
\hline & Ol4 & 0.830 & & \\
\hline & OI5 & 0.712 & & \\
\hline & Ol6* & 0.582 & & \\
\hline \multirow[t]{6}{*}{ Technological Innovation } & $\mathrm{TI} 1^{*}$ & 0.286 & 0.760 & 0.905 \\
\hline & $\mathrm{T} 12^{*}$ & 0.072 & & \\
\hline & $\mathrm{TI} 3^{*}$ & 0.605 & & \\
\hline & $\mathrm{T} 14$ & 0.888 & & \\
\hline & TI5 & 0.880 & & \\
\hline & TI6 & 0.847 & & \\
\hline \multirow[t]{10}{*}{ SME Performance } & HR1 & 0.778 & 0.625 & 0.893 \\
\hline & HR2 & 0.824 & & \\
\hline & $\mathrm{HR}^{*}$ & 0.336 & & \\
\hline & MR1 & 0.803 & & \\
\hline & MR2* & 0.495 & & \\
\hline & MR3* & -0.355 & & \\
\hline & MR4* & -0.135 & & \\
\hline & FR1 & 0.776 & & \\
\hline & FR2 & 0.771 & & \\
\hline & $\mathrm{FR}^{*}$ & 0.435 & & \\
\hline
\end{tabular}

Note: Composite reliability $(C R)=$ (square of the summation of the factor loadings)/ \{(square of the summation of the factor loadings) / (square of the summation of the error variances)

Average variance extracted $(\mathrm{AVE})=$ (summation of the square of the factor loadings $) /\{($ summation of the square of the factor loadings) / (summation of the error variances)\}

* Items was deleted due to poor loading

\section{Direct Effect and Mediation Analysis}

Based on Figure 1, there was an insignificant effect of TQM ( $\mathrm{p}=0.282)$ and SME performance and also an insignificant relationship identified between TQM and innovation ( $\mathrm{p}=0.510)$. However, the relationship between innovation and performance of SMEs was significant $(\mathrm{p}=0.012)$. With regard to this result, hypothesis $\mathrm{H} 1$ and $\mathrm{H} 2$ were not supported and only $\mathrm{H} 3$ in which the direct link between innovation and performance of SMEs has established a relationship. In order to examine the effect of the mediating variable, several procedures had to be done as proposed by Hair et al., 
2014). It involves a procedure which calculate the direct, indirect efect and the variance accounted for (VAF). The variance accounted for (VAF) can be calculated by using this formula; [indirect effect / total effect]. As a result based on the finding in SEM, the result of the direct effect of TQM and innovation (Table 2) is $0.606 \times 0.509=0.308$. While, Table 3 shows the result of the indirect effect of TQM and SMEs via innovation with the value of 0.308 . The next step was to calculate the total effect of TQM and SMEs. This was identified by adding the direct effect and indirect effect in which $[0.308+0.308=0.616]$. Therefore, the final VAF can be measured through dividing the indirect effect and total effect in which $0.308 / 0.616=$ 0.50 . By having the value of 0.50 or $50 \%$ of VAF, it is proven that there is a mediating effect of innovation (partial) between TQM and SME performance since it is between $20 \%$ and $80 \%$. Hence, hypothesis H4 was supported.

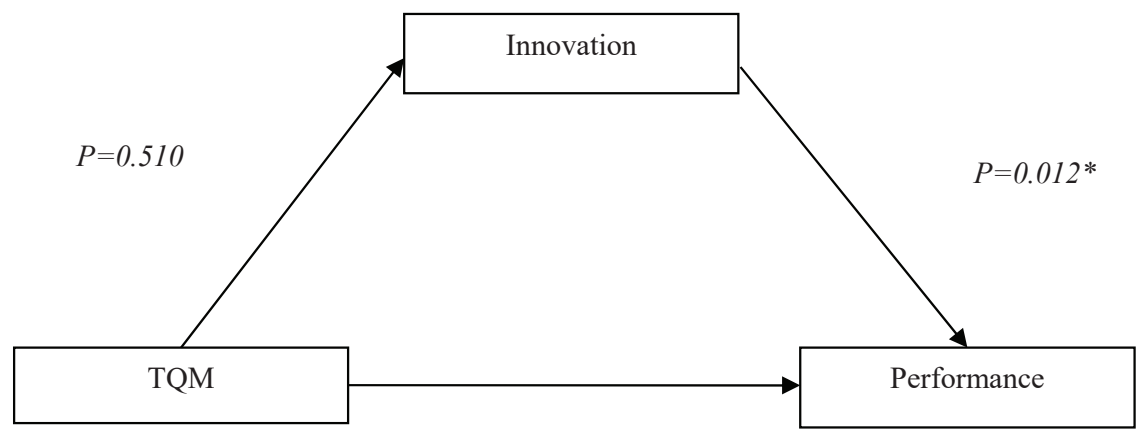

$P=0.282$

Figure 1: Model of TQM and Innovation as Predictor of Performance; Bootstrapping Result

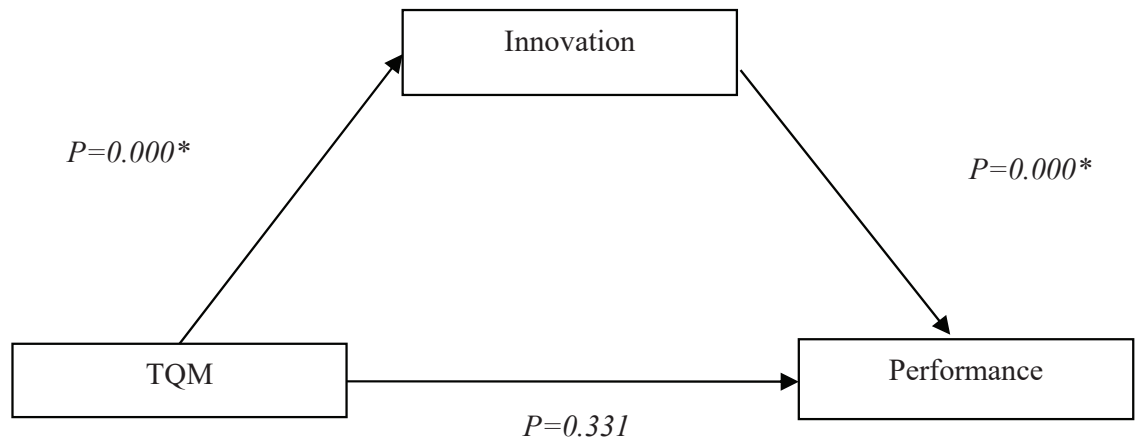

Figure 2: Model of TQM as Predictor of Performance, Mediated by Innovation 
Table 2: Significance Analysis of Path Coefficients with The Innovation as Mediator

\begin{tabular}{cccc}
\hline & Direct effect & & Indirect effect \\
\hline & TQM-INN & INN-SMEs & TQM-SMEs \\
OL-SMEs & $0.606\left(0.00^{* *}\right)$ & $0.509\left(0.00^{* *}\right)$ & $0.308\left(0.00^{* *}\right)$ \\
\hline
\end{tabular}

Table 3: Variance Accounted for (VAF) For Mediating Effect of Innovation

\begin{tabular}{cccc}
\hline & Direct effect & & Indirect effect \\
\hline & TQM-INN & INN-SMEs & TQM-SMEs \\
OL-INN-SMEs & $0.606\left(0.00^{* *}\right)$ & $0.509\left(0.00^{* *}\right)$ & $0.308\left(0.00^{* *}\right)$ \\
\hline
\end{tabular}

\section{Discussion}

This study examined the linkage between TQM and SME performance and the effect of innovation as mediator on that relationship. The finding of this study shows that TQM did not influence innovation and performance of SMEs in Malaysia. Moreover, this finding indicates that there is a relationship between TQM and performance, but need to be mediated by innovation. Results of the hypotheses are summarized in Table 4. The possible reason for the insignificant relationship might be related to sampling as the length of time in implementing TQM may be one affected. Factor as explained earlier, there is a variation of TQM implementation based on the duration of practice by organisations. In addition, the lack of adoption of TQM in several organisations in Malaysia especially in small business (Zakuan et al., 2012) might have also influenced this insignificant relationship.

SMEs could improve their activities by focusing more on innovation in bringing positive impacts towards their performance. Apparently, the presence of innovation activities within organisations will spur the efficiency of the process and thus influence the positive performance of SMEs. Concentrating on innovation as a business strategy is crucial in today's marketplace since it may give an impact for achieving a sustainable competitive edge (Gunday et al., 2011). Moreover, innovativeness applied in organisations gives an impact toward performance of SMEs (Olson \& Schwab, 2000) and some findings identified in this study are consistent with previous studies. 
Table 4: Result of Hypothesis Testing

\begin{tabular}{clc}
\hline Hypothesis & \multicolumn{1}{c}{ Relationship } & Result \\
\hline H1 & TQM à Performance & Not Supported \\
H2 & TQM à Innovation & Not Supported \\
H3 & Innovation à Performance & Supported \\
H4 & TQM à Innovation à Performance & Supported \\
\hline
\end{tabular}

The result also proved that TQM will only influence performance through the mediating effect of innovation as this strategic factor was found to be an effective strategy that can give a positive impact on performance of SMEs. This proves the need for innovation in improving the existing relationship of TQM and performance that is found to be insignificant in this study. However, since the relationship between TQM and innovation is found to be contradictory (H2), surprisingly, this variable is able to influence as a mediator between TQM and performance. This is believed to have happened due to the fact that innovation has a significant relationship with SME performance (H3), hence innovations in organisations still play an important role in improving SME performance.

\section{CONCLUSION}

This study also discovered that two hypotheses (direct relationship of TQM) are insignificant. However, the mediating effect of innovation on the relationship between TQM and SME performance was identified. Thus, it will provide a good basis for managerial implication to have an active involvement of practitioners of SMEs in Malaysia to participate on innovation activities, as this strategic orientation might influence innovativeness and at last will create a competitive advantage among SMEs especially in the emerging markets.

This study also makes a significant contribution to the field of SMEs in the context of a developing country. These findings provide evidence that innovation is an important strategic orientation for SMEs although the impact of TQM on SME performance and TQM on innovation were varied. Thus, empirical findings provided significant evidence that managers of SMEs in Malaysia believe that they are practising and developing this strategic 
orientation in their organisations due to the impact of innovation to both financial and non-financial performance of SMEs. Thus, SMEs in Malaysia are urged to adapt technological innovation in response to seek improvement in product decision and in quality especially for those companies that are related to and feed components or parts to large organisations.

This study employed a unique approach and differs from similar studies focusing on SMEs in Malaysia whereby there is a limited number of studies using SEM, especially a partial least squares method in testing the research model. This is supported by previous researchers who urged researchers to put more focus on testing the relationship between TQM and innovation by using SEM. Additionally, this study is also believed to contribute methodologically not only by identifying the critical success factors (CSFs) of TQM, but also in terms of selection and evaluation TQM practices within the SME settings in which this contribution is limited to the Malaysia context. Furthermore, because this study only measured the use of self-reported data and only concentrated on a quantitative analysis in examining the framework, it might be useful to employ mixed methods, which include a qualitative analysis to strengthen the research findings. In addition, the study can be extended to different industrial contexts, particularly in the service industry.

\section{REFERENCES}

Abdullah, F., Hamali, J., Rahman Deen, A., Saban, G., \& Zainoren Abg Abdurahman, A. (2009). Developing a framework of success of Bumiputera entrepreneurs. Journal of Enterprising Communities: People and Places in the Global Economy, 3(1), 8-24.

Akgün, A. E., Keskin, H., \& Byrne, J. (2009). Organisational emotional capability, product and process innovation, and firm performance: An empirical analysis. Journal of Engineering and Technology Management, 26(3), 103-130.

Arinaitwe, S. K. (2006). Factors constraining the growth and survival of small scale businesses. A developing countries analysis. Journal of American Academy of Business, 8(2),167-179 
Asia News Monitor (2011). Asia: Asian SMEs playing bigger role. (2010, Oct 18). Retrieved from http://search.proquest.com.ezaccess.library.u itm.edu.my/docview/1243275459? accountid $=42518$

Aziz, R. A., Mahmood, R., Tajudin, A., \& Abdullah, M. H. (2014). The relationship between entrepreneurial orientation and business performance of SMEs in Malaysia. International Journal of Management Excellence, 2(3), 221-226.

Brah, S. A., \& Ying Lim, H. (2006). The effects of technology and TQM on the performance of logistics companies. International Journal of Physical Distribution \& Logistics Management, 36(3), 192-209.

Calantone, R. J., Cavusgil, S. T., \& Zhao, Y. (2002). Learning orientation, firm innovation capability, and firm performance. Industrial Marketing Management, 31(6), 515-524.

Camisón, C., \& Villar-López, A. (2014). Organisational innovation as an enabler of technological innovation capabilities and firm performance. Journal of Business Research, 67(1), 2891-2902.

Carmona-Márquez, F. J., Leal-Millán, A. G., Vázquez-Sánchez, A. E., Leal-Rodríguez, A. L., \& Eldridge, S. (2016). TQM and business success: Do all the TQM drivers have the same relevance? An empirical study in Spanish firms. International Journal of Quality \& Reliability Management, 33(3), 361-379.

Danyen, S., \& Callychurn, D. S. (2015). Total quality management success factors and their relationships with performance measures in the food industry: A Mauritian case study. International Journal of Productivity and Quality Management, 16(3), 249-266.

Dedy, A. N., Zakuan, N., Omain, S. Z., Rahim, K. A., Ariff, M. S. M., Sulaiman, Z., \& Saman, M. Z. M. (2016, May). An analysis of the impact of total quality management on employee performance with mediating role of process innovation. In IOP Conference Series: Materials Science and Engineering, 131(1),1-9. 
Elmuti, D., Kathawala, Y., \& Manippallil, M. (1996). Are total quality management programmes in higher education worth the effort? International Journal of Quality \& Reliability Management, 13(6), $29-44$.

Fornell, C. \& Larcker, D. F. (1981). Evaluating structural equation models with unobservable variables and measurement error. Journal of Marketing Research, 18(1), 39-50.

Gunday, G., Ulusoy, G., Kilic, K., \& Alpkan, L. (2011). Effects of innovation types on firm performance. International Journal of Production Economics, 133(2), 662-676.

Hair, J. F., Black, W. C., Babin, B. J., \& Anderson, R. E. (2010). Multivariate data analysis: A global perspective. Upper Saddle River: Pearson.

Hair, J. F., Hult, G. T. M., Ringle, C. M. \& Sarstedt, M. (2014). A primer on partial least squares structural equation modeling. Thousand Oaks, CA: Sage.

Hubiak, W. A., \& O’Donnell, S. J. (1996). Do Americans have their minds set against TQM?. National Productivity Review, 15(3), 19-32.

Jabeen, R., Shehu, A. M., Mahmood, R., \& Bambale, A. J. (2015). Total quality management dimensions and SME performance: A quantitative approach. International Postgraduate Business Journal, 7(1), 21-35.

Keskin, H. (2006). Market orientation, learning orientation, and innovation capabilities in SMEs: An extended model. European Journal of Innovation Management, 9(4), 396-417.

Laforet, S. (2011). A framework of organisational innovation and outcomes in SMEs. International Journal of Entrepreneurial Behavior \& Research, 17(4), 380-408.

Lin, C. Y.-Y., \& Chen, M. Y.-C. (2007). Does innovation lead to performance? An empirical study of SMEs in Taiwan. Management Research News, 30(2), 115-132. 
Maçães, M. A. R., Farhangmehr, M., \& Pinho, J. C. (2007). Market orientation and the synergistic effect of mediating and moderating factors on performance: The case of the fashion cluster. Portuguese Journal of Management Studies, 12(1), 27-44.

Malaysian Science and Technology Information Centre, MASTIC. (2011). National Survey of Innovation 2005-2008. Ministry of Science, Technology and Innovation.

Mat Yunoh, M. N., \& Mohd Ali, K. A. (2015). Total quality management approach for Malaysian food industry: Conceptual framework. International Journal of Business and Social Science, 6(1), 152-161.

McDermott, C. M., \& Prajogo, D. I. (2012). Service innovation and performance in SMEs. International Journal of Operations \& Production Management, 32(2), 216-237.

Ng, H. S., \& Kee, D. M. H. (2012). The issues and development of critical success factors for the SME success in a developing country. International Business Management, 6(6), 680-691.

Noruzy, A., Dalfard, V. M., Azhdari, B., Nazari-Shirkouhi, S., \& Rezazadeh, A. (2012). Relations between transformational leadership, organisational learning, knowledge management, organisational innovation, and organisational performance: An empirical investigation of manufacturing firms. The International Journal of Advanced Manufacturing Technology, 64, 1073-1085.

Oke, A., Burke, G., \& Myers, A. (2007). Innovation types and performance in growing UK SMEs. International Journal of Operations \& Production Management, 27(7), 735-753.

Oke, M. A., \& Oke, O. D. (2014). Exploring the link between total quality management and business performance. European Journal of Business and Management, 6(9), 75-86.

Olson, C. A., \& Schwab, A., (2000). The performance effects of human resource practices: The case of interclub networks in professional baseball, 1991-1940. Industrial Relations, 39, 553-577. 
Pinho, J. C. (2008). TQM and performance in small medium enterprises: The mediating effect of customer orientation and innovation. International Journal of Quality \& Reliability Management, 25(3), 256-275.

Ruiz-Moreno, A., Tamayo-Torres, J., \& García-Morales, V. J. (2015). The role of QMS in the relationship between innovation climate and performance. Production Planning \& Control, 26(11), 841-857.

Sadikoglu, E., \& Zehir, C. (2010). Investigating the effects of innovation and employee performance on the relationship between total quality management practices and firm performance: An empirical study of Turkish firms. International Journal of Production Economics, 127(1), $13-26$.

Salaheldin, S. I. (2009). Critical success factors for TQM implementation and their impact on performance of SMEs. International Journal of Productivity and Performance Management, 58(3), 215-237.

SME Corporation Malaysia. (2012). SME Annual Report (2011/12). from http:// www.smecorp.gov.my

SME Corporation Malaysia. (2015). SME Annual Report (2014). Retrieved May 23, 2016 from http:// www.smecorp.gov.my

Yusr, M. M., Mohd Mokhtar, S. S., \& Othman, A. R. (2014). The effect of TQM practices on technological innovation capabilities: Applying on Malaysian manufacturing sector. International Journal for Quality Research, 8(2), 197-216.

Zakuan, N., Muniandy, S., Saman, M. Z. M., Ariff, M. S. M., Sulaiman, S., \& Jalil, R. A. (2012). Critical success factors of total quality management implementation in higher education institution: A review. International Journal of Academic Research in Business and Social Sciences, 2(12), 19-32.

Zehir, C., Ertosun, Ö. G., Zehir, S., \& Müceldilli, B. (2012). Total Quality Management practices' effects on quality performance and innovative performance. Procedia - Social and Behavioral Sciences, 41, 273-280. 